\title{
Tranformational Leadership Effect On The Marketing Performance Through Market Orientation
}

\author{
Muslichah Erma Widiana \\ Bhayangkara University, Surabaya, Indonesia
}

\begin{abstract}
Regional Enterprise or so-called enterprises can play an important role for the region in particular and national development in general. As one source of local revenue or $P A D$ in addition to tax and retribution, so that the management of enterprises require a serious and professional. Leadership is important to be discussed based on the consideration that, first, theoretically, leadership is positioned as the central factor that dominate, moving, directing, and coordinating various other factors within the organization. Leaders are needed for determining the continuity and development of business. Secondly, referring to previous research that leadership is a factor that significantly influence market orientation, organizational innovation and organizational performance. The purpose of this study was to: (1) test and analyze the effect of transformational leadership on market orientation; (2) to test and analyze the effect of transformational leadership on organizational innovation; (3) to test and analyze the effect of market orientation on performance marketing; (4) test and analyze the effect of innovation on the performance of marketing organizations; (5) to test and analyze the effect of market orientation on organizational innovation; (6) test and analyze the effect of transformational leadership on marketing performance.
\end{abstract}

Keywords: transformational leadership, marketing performance, market orientation, organizational innovation.

\section{INTRODUCTION}

Leadership is important to be discussed based on the consideration that, first, theoretically, leadership is positioned as the central factor that dominate, moving, directing, and coordinating various other factors within the organization. Leaders are needed for determining the continuity and development of business, the situation of uncertainty that any time could threaten the business, and his influence because the leader has a base of power and authority. Secondly, referring to previous research that leadership is a factor that significantly influence market orientation, organizational innovation and organizational performance (Gana, 2004).

The influence of leadership on organizational innovation presented King and Anderson (Gana, 2004). Initially, the effect of leadership on innovation organizations focused on individual characteristics, values and beliefs, experience and knowledge and so on. Values among the leaders is predictive of innovation (Gana, 2004). The difficulty of these earlier studies that have not been able to identify various characteristics of the types of leadership that affect innovation. Moreover, in the study of the characteristics of a leader who is found associated with organizational innovation, also turns out that other variables showed a strong relationship with organizational innovation. In a study on the effects of leadership on organizational performance, found that leaders having an influence on organizational performance (Yukl, 2009). 
Market orientation is a popular term used by practitioners in the field of marketing as implementations and marketing concepts. More than four decades, market-oriented corporate strategy is seen by academics and practitioners as the main pillar for achieving superior corporate performance at manufacturing as well as in companies services (Kara, 2005). This is consistent with that proposed by Ellis (2006) in his study states that evidence obtained from meta $\urcorner$ quantitative analysis of 56 studies (58 samples) were conducted in 28 countries proves that in general the market orientation determines the performance of the company.

Agarwal et al. al., (2003) conducted a study of 201 General Manager Standard hotel international in the United States is found that market orientation has a positive influence on innovation, this innovation will encourage the achievement of the performance subjectively in the company, which in turn will encourage the achievement of the performance objective within the company, thus the make companies that have a high degree of market orientation will be more innovative than its competitors.

Regional Enterprise or so-called enterprises can play an important role for the region in particular and national development in general. As one source of local revenue or PAD in addition to tax and retribution, so that the management of enterprises require a serious and professional. East Java Provincial Government enterprises are divided into several areas, namely: Finance, Other Business, Water and Gas. There were six enterprises East Java Province, namely: (1) PT Petrogas Jatim Utama engaged in oil and gas; (2) PT. Asuransi Bangun Askrida engaged in the financial sector; (3) PT. East Java RB engaged in the financial sector; (4) PT. East Java Regional Development Bank Tbk is engaged in the financial sector; (5) PT. Java Jamkrida engaged in the financial sector; (6) Regional Water Company is engaged in the provision of clean water.

The purpose of this study was to: (1) test and analyze the effect of transformational leadership on market orientation; (2) to test and analyze the effect of transformational leadership on organizational innovation; (3) to test and analyze the effect of market orientation on performance marketing; (4) test and analyze the effect of innovation on the performance of marketing organizations; (5) to test and analyze the effect of market orientation on organizational innovation; (6) test and analyze the effect of transformational leadership on marketing performance.

\section{Transformational leadership}

\section{LITERATURE REVIEWS}

Transformational leadership, the followers feel the trust, admiration, loyalty, and respect for leaders and followers are motivated to make a greater effort on the expected and previously (Yukl, 2009). Transformational leadership involves aspects such as value, trust, integrity, fairness, ethics, vision, charisma, agents of change, communication, clarity of objectives and standards (Avolio and Bass 2002).

Rafferty and Griffin (2004) underlines the transformative effect of the transformational leadership for the organization and also for individuals. Often said that by defining the need for change, the creation of new visions, and mobilize commitment to the visions of the leaders will be able to transform the organization. 
Indicators is a transformational leadership (Bass, 1997):

\section{Charisma}

Charismatic leadership with regard to the reaction subordinate to the leader and the leader's behavior. Leaders are identified with a model made by a subordinate, trusted, respected, have a clear vision and mission, which according to the perception of subordinates can be realized. The leader sets high standards and sass iran challenging for subordinates (Yukl, 2009).

\section{Motivation Inspiration}

Inspirational leader by Bass and Avolio (Yukl, 2009) is defined as the extent to which a leader is able to communicate a vision, able to use the symbols to focus the efforts of subordinates and to model appropriate behavior. An inspirational leader who is able to provide visions of what is possible and how to obtain it.

\section{Intellectual Stimulation}

Intellectual stimulation is an effort to raise awareness of subordinate leaders to issues and influencing subordinates to look at these issues from the perspective of a barn (Yukl, 2009).

\section{Individual Attention}

Yukl (2009) argued that delegation of authority is the focus of attention individual.Pendelegasian some of the tasks to be completed by subordinates is a challenge for subordinate work and provide opportunities for subordinates to learn.

\section{Market Orientation}

Indicators of market orientation can be explained as follows:

\section{Customer orientation}

According Despande, Farley and Webster (Tjiptono et al, 2008: 91), customer orientation is the highest priority in terms of delivering superior value to customers in the research conducted by considers customer orientation is the most fundamental thing for the company. A customer is the most important side of the company's customer orientation menenttukan. Customer orientation is a sufficient understanding of the buyers, the target of the buyer is able to create superior value for them continuously and create a more superior performance for the company. The creation of the appearance will strengthen the company's position to be able to determine the orientation of the customers that will be addressed. Customer orientation requires a seller to understand the whole value chain of a buyer. Through customer orientation, the company has an opportunity to shape customer perceptions over the perceived values that in turn will generate customer satisfaction (Tjiptono et al, 2008: 92)

\section{Orientation competitors}

Competitor orientation means understanding who owned the seller in understanding the power - short-term strength, weakness - weakness, capability and strategy capabilities - good long-term strategy of its main competitors today and competitors - the main potential competitor (Day and Wensly, 1992). Therefore, salespeople should seek to gather information on competitors and share your information on the function - other functions within the company and discuss with the leadership of the company how competitors' strengths and the strategies they develop to the company was able to anticipate the threat of competitors and survive in the competition. 
In fact customer orientation are often less able to be used as a strategy to win business competition, because companies tend to be reactive to emerging business issues and develop a proactive attitude in outclassing his business (Day and Wensley, 1992). Therefore need a balance in the second run of this orientation in order to win the competition on the one hand and on the other hand still satisfying customers. When a company focuses on just one course in ekskusif focus is on competition, this action may lead to the neglect of the interests of customers. For that submitted a balanced mix between customer orientation with competitor orientation as a prerequisite for maintaining a competitive advantage.

\section{Coordination between functions}

Coordination among these functions is essential for the survival of companies that want to give satisfaction to the customers as well as winning the competition by optimizing functions functions within the company carefully. This step as well as a company's ability to capture feedback from customers, respond and provide more excellent service at a later date (Kohli and Jaworski, 1993). The openness of communication between business functions are indispensable in giving feedback to the customer. The problems that arise from one function can be assisted ananlisis and the solution of the function - other functions professionally and conceptually. Similarly to the problem - a problem that can not be solved in one part can be discussed and taken steps - steps to resolve through coordination functions - functions within the company. This step needs to be socialized in the corporate culture so that employees do not close themselves, dare to take the initiative and are not afraid to take risks (Han et al, 1998).

\section{Organizational innovation}

Organizational innovation is defined as the adoption of new ideas or behavior within the organization (Damanpour, 1991). Dimensi $\neg$ dimensi Innovation involving all the organization's activities, products and services such as barn or new production process technologies, structures and new administrative systems, or planning or a new program within the organization.

Nasution (2005) adapted the three types of organizational innovation is product innovation, process innovation, and innovation administration. The argument underlying namely that of radical innovation and gradually more tep: as the characteristics of innovation while innovation of products, processes and administration is more a kind of innovation. This means that the radical and incremental innovation is part of the four above-mentioned innovations. Tainnya reason is that radical innovation and incremental basically describes the intensity and rate of change in the organization, although both are difficult to quantify. Furthermore, technical innovation related to process and product innovation that represents the adoption of new ideas that directly or indirectly affect the process and new products.

Indicators of organizational innovation can be explained as follows:

\section{Product innovations}

Product innovation is defined as new products or services introduced to the market to meet the needs of the market (Damanpour, 1991). Furthermore, product innovation is defined by Lukas and Ferrell (2000) as the process of introducing a new technology to be used. The result of this process is the introduction of new products or services that can be used as a tool to gain an advantage for the company. 


\section{Innovation process}

Process innovation is defined as a new element introduced in operation in the company's products and services, such as the material of raw materials, specifications titugas, the mechanism of action and information, as well as the equipment used to produce the product or service (Damanpour, 1991).

\section{Innovation administration}

Administration innovation associated with changes in the method of business operations that can take advantage of these changes effectively in the structure and policies of the organization, working methods ,, and other procedures to produce, finance, and marketing products or services (Cooper, 1998). Innovation administration also involves changes that affect organizational policies, resource allocation, and other factors related to the social structure of the organization (Cooper, 1998), which is indirectly related to the activities of the organization (Han et al., 1998).

\section{Marketing Performance}

Marketing performance is a concept to measure the market performance of a product. Any company interested to know the market performance of the product - the product, as a mirror of its business success in the competitive world of business. In addition the company's performance can be done in two ways, both internally and externally. Especially externally improving corporate performance is done by using an approach oriented culture in the market (market orientation), namely how to understand the needs, wishes and market demand. In the application of these efforts into one needs to do in order to optimize business performance. Market orientation has an equally important role and can contribute to the improved performance of the company (Hatani, 2000: 3).

According Tjiptono et al (2008: 239) the measurement of marketing performance is based on the profitability and productivity of marketing decisions. Profitability analysis based on assessments to examine the effect of various strategies and marketing programs on the profit contribution of a product or service. While productivity is based on the consequences of sales or market share resulting from the application of certain marketing strategies

\section{Relationship between Variables}

\section{Effect of Transformational Leadership on Market Orientation}

The theory used in the influence of transformational leadership on market orientation is the market orientation theory. In this theory, it is said that the development of market orientation in a company is not a simple issue. Among the corporate culture that has evolved well established within the company. Studies conducted by Jaworski and Kohli (1993) showed that diperiukan additional factor to be able to apply and develop the market orientation in a company.

In the context of marketing, when a company will direct the business beroerientasi business into the market, then the style of leadership is a critical factor affecting the success of the implementation of the company's market orientation (Harris and Ogbonna, 2001). This is because the leadership is very influential in the life of the company as a whole, including the creation of a conducive climate bagi.tumbuhnya company marketing culture. Based on the above, it can be made the hypothesis in this study:

H1: Transformational leadership influence on market orientation 


\section{Effect of Transformational Leadership on Organizational Innovation}

The theory used in the influence of transformational leadership on organizational innovation is a transformational versus transactional leadership theory. In this theory say that promoting organizational innovation requires transformational leadership to face the new economic era based on intellectual capital. Transformative leadership enables organizations to learn and innovate through experimentation $\neg$ dialog - private procurement - knowledge organization (Senge et al., 1994).

Transformative leader creates ideal conditions for organizational innovation by bringing together a team of innovative people, promote mutual trust, take risks, and a shared vision among the members of the organization and minimize the cost of internal communications (Dess and Picken, 2000).

Based on the above, it can be made the hypothesis in this study:

H2: Transformational leadership influence on organizational innovation

\section{Effect of Market Orientation on Performance Marketing}

The theory used in the influence of market orientation on the performance of the organization is the market orientation theory. Market orientation setting up a company with "unity of effort and focus on the activities of individuals and departments within the organization, resulting in superior performance" (Kohli and Jaworski, 1993). In addition, the function to obtain information about the needs of the market and then to adjust decisions based on market information. As a result, the company finally better match the needs of the market, thus increasing customer satisfaction and loyalty (Kohli and Jaworski, 1993). In this sense, in line with the findings of other authors, it can be said that market orientation has a direct impact, positive and significant impact on performance.

Most of the literature agrees that market orientation has a positive impact on performance because it is a resource that helps companies to create superior long-term value for customers (Morgan, 1998).

H3: market orientation on the performance of marketing

\section{Influence of Organizational Innovation on Performance Marketing}

Innovation is very important for the economic efficiency of enterprises and the country and is one of the main drivers of long-term success of the company, especially in a dynamic market (Baker and Sinkula, 2002). Organizations must innovate to be effective and, in the long term, in order to survive (Damanpour and Schneider, 2006).

H4: Organizational Innovation on the performance of marketing

\section{Effect of Market Orientation on Organizational Innovation}

Research Han, Kim and Srivastava (1996) A key objective of this study was to examine the role of innovation organizations that play a role in the context of the relationship between market orientation and business performance. consumer orientation as the dominant factor responsible for this phenomenon: the main effect of customer orientation is the highest and significant impact on organizational innovation.

H5: Market Orientation on Organizational Innovation 


\section{Transformational Leadership Influence on Marketing Performance}

Gowen et at (2009) revealed that transformational leadership and quality management improve knowledge management. Also, transformational leadership is fully mediated by the response of knowledge and quality management is partially mediated by the response of knowledge on organizational performance. Pillai and Williams (2004) states transformational leadership affect performance.

H6: Transformational Leadership on Marketing Performance

\section{Research Model}

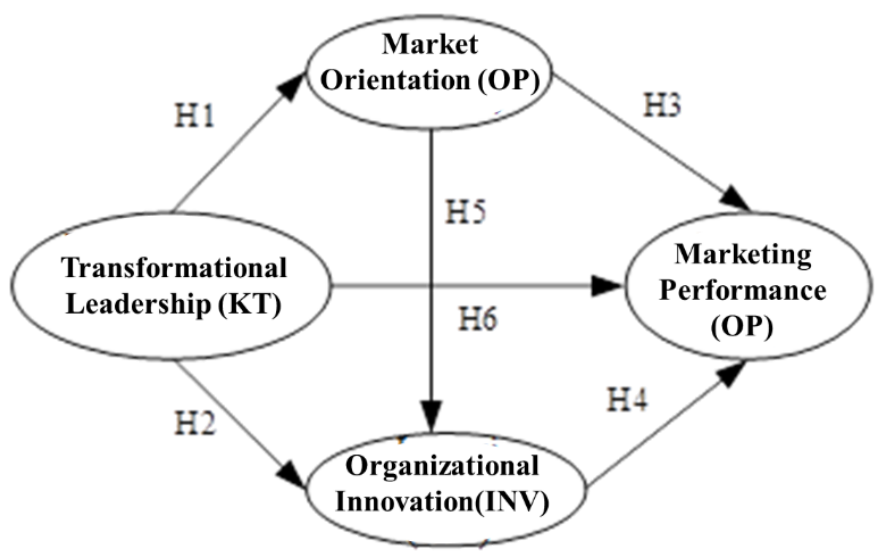

Fig. 1. Research model and relation between variables

\section{Population and Sample}

\section{RESEARCH METHODOLOGY}

This study is a survey of population in this study were employees of Regional Enterprise East Java, consisting of 6 (six) enterprises: PT. Petrogas Jatim Utama, PT. Asuransi Bangun Askrida, PT. BPR East Java, PT. East Java Regional Development Bank Tbk, PT. Jamkrida East Java, and the Regional Water Supply Company. Samples were taken from the heads of division and staff in six enterprises amounted to around 110 employees.

\section{Measurement Variable}

Measurement of variables in this study are shown in Table 1 
Table 1. Variables, dimensions and indicators

\begin{tabular}{|c|c|c|c|}
\hline No & Variabel & Dimension & Indicators \\
\hline \multirow{8}{*}{1} & \multirow{8}{*}{$\begin{array}{l}\text { Transformational } \\
\text { leadership }\end{array}$} & \multirow{2}{*}{$\begin{array}{l}\text { Charisma } \quad \text { (ideal } \\
\text { influence) }\end{array}$} & Give example (KT1) \\
\hline & & & Growing optimism (KT2) \\
\hline & & \multirow{2}{*}{$\begin{array}{l}\text { Inspirational } \\
\text { motivation }\end{array}$} & Providing motivation (KT3) \\
\hline & & & Giving idea (KT4) \\
\hline & & \multirow[t]{2}{*}{ Intellectual stimulation } & Innovative push (KT5) \\
\hline & & & Involvement of decision making (KT6) \\
\hline & & \multirow[t]{2}{*}{ Individual attention } & Giving directions (KT7) \\
\hline & & & Give awards (KT8) \\
\hline \multirow{4}{*}{2} & \multirow{4}{*}{ Market orientation } & Intellegent generation & Meet customers (OP1) \\
\hline & & $\begin{array}{l}\text { Intellegent } \\
\text { dissemination }\end{array}$ & $\begin{array}{l}\text { Dissemination of customer satisfaction } \\
\text { data (OP2) }\end{array}$ \\
\hline & & \multirow{2}{*}{$\begin{array}{l}\text { Intellegent } \\
\text { responsiveness }\end{array}$} & Product development review (OP3) \\
\hline & & & Listening to customer complaints (OP4) \\
\hline \multirow{6}{*}{3} & \multirow{6}{*}{$\begin{array}{l}\text { Organizational } \\
\text { innovation }\end{array}$} & \multirow[t]{2}{*}{ Process innovation } & Fixed work practices (INV1) \\
\hline & & & Routine train employees (INV2) \\
\hline & & \multirow[t]{2}{*}{ Product innovation } & Creating new services (INV3) \\
\hline & & & Creating service modifications (INV4) \\
\hline & & \multirow{2}{*}{$\begin{array}{l}\text { Administrative } \\
\text { innovation }\end{array}$} & Developing new ideas (INV5) \\
\hline & & & Encouraging initiative (INV6) \\
\hline \multirow{3}{*}{4} & \multirow{3}{*}{ Marketing performance } & $\begin{array}{l}\text { Operational } \\
\text { performance }\end{array}$ & $\begin{array}{l}\text { The number of complaints decreases } \\
\text { (Kin1) }\end{array}$ \\
\hline & & \multirow{2}{*}{ Market performance } & Increased market share (Kin2) \\
\hline & & & New customers are increasing (Kin3) \\
\hline
\end{tabular}

\section{Data Analysis Techniques}

Structural Equation Modeling (SEM) is a statistical technique that performs a relatively complex and simultaneous set of relationships. The relationship can be constructed between one or several variables depending on one or more independent variables and can take the form of a factor or construction, constructed from several indicator variables. The variables can be either a single variable that is observed or measured directly (Ferdinand, 2002). 


\section{Confirmatory Analysis of Exogenous Constructs \\ RESULT ANALYSIS AND DISCUSSION}

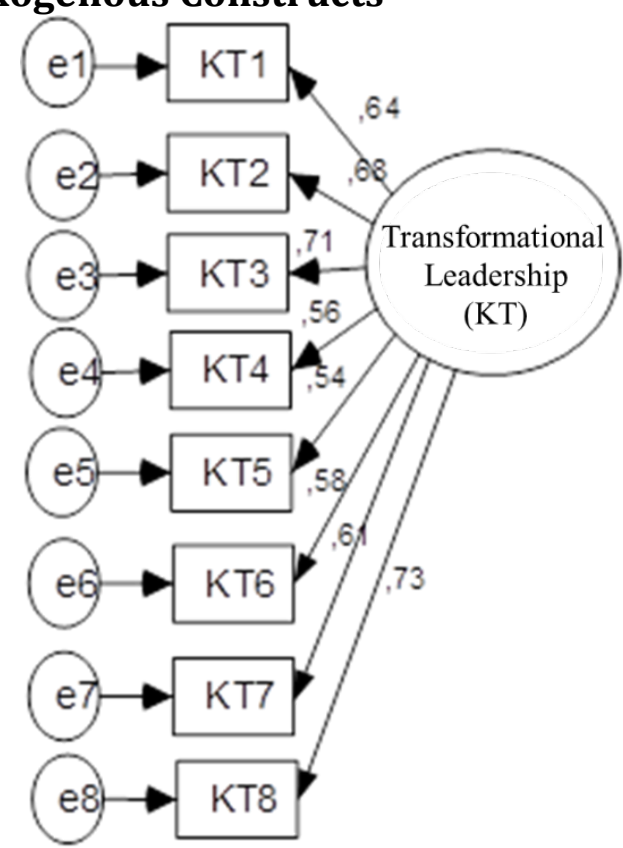

Fig.2. Results Analysis of Exogenous Factors

Table 2. Result Analysis Confirmation Factor of Transformational Leadership

\begin{tabular}{|l|r|r|l|}
\hline Indicator & Loading & Critical Ratio & Inf. \\
\hline KT1 & 0,643 & 5,456 & Valid \\
\hline KT2 & 0,681 & 5,981 & Valid \\
\hline KT3 & 0,714 & 6,232 & Valid \\
\hline KT4 & 0,562 & 4,345 & Valid \\
\hline KT5 & 0,543 & 3,124 & Valid \\
\hline KT6 & 0,584 & 4,523 & Valid \\
\hline KT7 & 0,611 & 5,211 & Valid \\
\hline KT8 & 0,733 & 6,945 & Valid \\
\hline Construct reliability $=0,8411$ & \\
\hline
\end{tabular}

Based on table 2 it can be seen that the critical ratio (CR) value of eight transformational leadership indicators greater than 1.96, it can be concluded that the eight indicators are valid form the transformational leadership constructs. The construct reliability value of $0.8411>$ 0.700 indicates that the eight indicators are reliable. 


\section{Confirmatory Analysis of Endogenous Constructs}

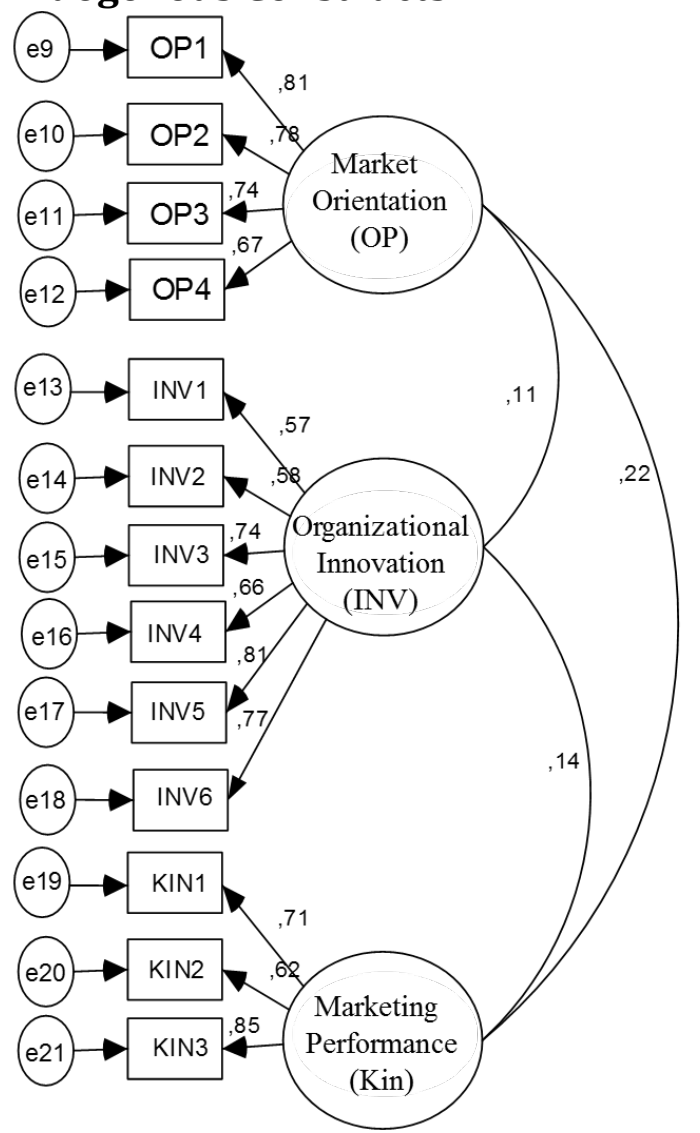

Fig. 3. Result Analysis of Endogenous Factor

Table 3. The Result of Market Orientation Confirmation Factor Analysis

\begin{tabular}{|l|c|c|l|}
\hline Indicators & Loading & Critical Ratio & \multicolumn{1}{|c|}{ Inf. } \\
\hline OP1 & 0,813 & 6,713 & Valid \\
\hline OP2 & 0,782 & 5,912 & Valid \\
\hline OP3 & 0,745 & 5,144 & Valid \\
\hline OP4 & 0,672 & 4,234 & Valid \\
\hline \multicolumn{4}{|l}{ Construct reliability $=0,8406$} \\
\hline
\end{tabular}

Based on table 3 it can be seen that the critical ratio (CR) value of four indicators of Market Orientation is greater than 1.96, it can be concluded that the eight indokors are valid in forming Market Orientation constructs. The value of construct reliability is $0.8406>0.700$, indicating that the four indicators are reliable.

Table 4. The Result of Organizational Innovation Confirmation Factor Analysis

\begin{tabular}{|l|r|r|l|}
\hline Indicator & Loading & Critical Ratio & Inf. \\
\hline INV1 & 0,572 & 5,145 & Valid \\
\hline INV2 & 0,581 & 6,121 & Valid \\
\hline INV3 & 0,744 & 10,112 & Valid \\
\hline INV4 & 0,663 & 8,355 & Valid \\
\hline INV5 & 0,813 & 11,713 & Valid \\
\hline INV6 & 0,774 & 10,561 & Valid \\
\hline \multicolumn{5}{|l}{ Construct reliability $=0,8480$} \\
\hline
\end{tabular}


Based on table 4. it can be seen that the critical ratio value (CR) of the six indicators of Organizational Innovation is greater than 1.96, it can be concluded that the six indicators are valid form the construct of Organizational Innovation. The value of construct reliability is $0.8480>0.700$, indicating that the six indicators are reliable.

Tabel 5. The Result of Marketing Performance Confirmation Factor Analysis

\begin{tabular}{|l|r|r|l|}
\hline Indicator & Loading & Critical Ratio & Inf. \\
\hline KIN 1 & 0,713 & 9,345 & Valid \\
\hline KIN 2 & 0,623 & 7,334 & Valid \\
\hline KIN 3 & 0,854 & 10,356 & Valid \\
\hline \multicolumn{2}{l}{ Construct reliability $=0,7773$} \\
\hline
\end{tabular}

Based on table 5. it can be seen that the critical ratio (CR) value of three indicators of Market Performance is greater than 1.96, it can be concluded that the three indicators are valid form the construct of Market Performance. The value of construct reliability is $0.7773>0.700$, indicating that the three indicators are reliable.4.3.

\section{Result of Structural Equation Model}

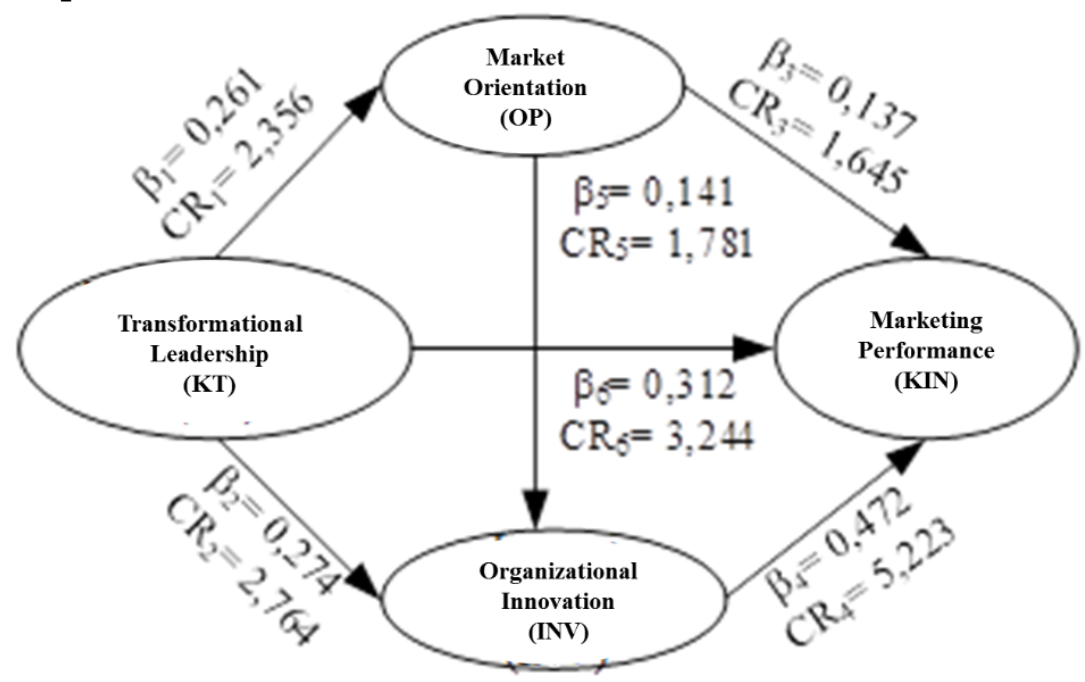

Fig. 4. Structural Equation Model Result

The result of structural equation model analysis and hypothesis testing can be seen in table 6 . 
Tabel 6. Hasil Pengujian Hipotesis

\begin{tabular}{|l|l|c|c|l|}
\hline Hip & Relationship between variables & $\begin{array}{c}\text { Path } \\
\text { coefficient }\end{array}$ & CR & Information \\
\hline H1 & $\begin{array}{l}\text { Transformational leadership } \rightarrow \text { market } \\
\text { orientation }\end{array}$ & 0,261 & 2,356 & significant \\
\hline H2 & $\begin{array}{l}\text { Transformational leadership } \\
\text { organizational innovation }\end{array}$ & 0,274 & 2,764 & Significant \\
\hline H3 & $\begin{array}{l}\text { Market orientation } \rightarrow \text { marketing } \\
\text { performance }\end{array}$ & 0,137 & 1,645 & $\begin{array}{l}\text { not } \\
\text { significant }\end{array}$ \\
\hline H4 & $\begin{array}{l}\text { Organizational innovation } \rightarrow \text { marketing } \\
\text { performance }\end{array}$ & 0,472 & 5,223 & Significant \\
\hline H5 & $\begin{array}{l}\text { Transformational leadership } \rightarrow \text { marketing } \\
\text { performance }\end{array}$ & 0,141 & 1,781 & $\begin{array}{l}\text { not } \\
\text { significant }\end{array}$ \\
\hline H6 & $\begin{array}{l}\text { Market orientation } \rightarrow \text { organizational } \\
\text { innovation }\end{array}$ & 0,312 & 3,244 & significant \\
\hline
\end{tabular}

Based on table 6. can be explained as follows:

1. The value of the transformational leadership path coefficient $\rightarrow$ market orientation of 0.261 and the critical ratio value of 2.356> 1.96, indicating that transformational leadership has a significant effect on market orientation. Hypothesis 1 (H1) which states transformational leadership affect the accepted market orientation.

2. The value of the transformational leadership path coefficient $\rightarrow$ organizational innovation of 0.274 and the critical ratio value of $2.764>1.96$, indicating that transformational leadership has a significant effect on organizational innovation. Hypothesis 2 (H2) which states transformational leadership influence on organizational innovation accepted.

3. The coefficient of market orientation coefficient $\rightarrow$ marketing performance of 0.137 and the critical ratio value of $1.645<1.96$, indicating that market orientation has no significant effect on organizational innovation. Hypothesis 3 (H3) which states the market orientation affect the marketing performance is rejected.

4. The coefficient of organizational innovation pathway $\rightarrow$ marketing performance of 0.472 and critical ratio value of 5,223>1,96, indicating that organizational innovation has significant effect to marketing performance. Hypothesis 4 (H4) which states that organizational innovation has an effect on acceptable marketing performance.

5. The value of path coefficient Transformational leadership $\rightarrow$ marketing performance of 0.141 and critical ratio value of $1.781<1.96$, indicating that transformational leadership has no significant effect on marketing performance. Hypothesis 5 (H5) which states that transformational leadership influences the marketing performance is rejected.

6. The coefficient of market orientation coefficient $\rightarrow$ organizational innovation is 0,312 and critical ratio value $3,244>1,96$, indicating that market orientation has significant effect to organizational innovation. Hypothesis 6 (H6) which states the market orientation effect on organizational innovation is accepted.

\section{DISCUSSION}

\section{The Influence of Transformational Leadership to Market Orientation}

Based on the results of SEM analysis shows that transformational leadership has a significant effect on market orientation. The results of this study support the Market Orientation Theory (Harris and Ogbonna, 2001), the earliest study on the development of market orientation. Top management top leadership style has a process of developing market orientation. Managers 
and executives often support the improvement of the market orientation level but in different ways.

\section{The Influence of Transformational Leadership on Organizational Innovation}

Based on the results of SEM analysis shows that transformational leadership has a significant effect on organizational innovation. The findings of this study support transformational leadership theories and expand the research of Senge (1994) which states that transformational leaders have the vision and attention to effective communication and share values and encourage an environment suited for team innovation. Transformational leadership styles can provide an important individual influence on corporate innovation. This leadership style can also directly introduce new ideas into the organization.

The results of this study also support the results of previous research Dess and Picken (2000), that organizational managers should encourage members of the organization to achieve higher levels in the mastery of personal vision. This action is done to overcome internal and external obstacles in achieving the vision of the organization.

\section{The Effect of Market Orientation on Marketing Performance}

Based on the results of SEM analysis shows that market orientation has no significant effect on marketing performance. The results of this study do not support the results of research Kohli and Jaworski (1993). The results of this study indicate that the ability of BUMD to achieve organizational goals such as increased profitability is not followed by the company's ability to determine the needs and wants of the target market and satisfy it more effectively and efficiently than its competitors.

\section{The Influence of Organizational Innovation on Marketing Performance}

Based on the results of SEM analysis shows that Organizational Innovation has a significant effect on marketing performance. The results of this study support the theory of organizational innovation which states that innovation capacity such as the introduction of new products, new service process is relvan with company capacity to participate in organizational innovation.

\section{The Influence of Market Orientation To Organizational Innovation}

Based on the results of SEM analysis shows that market orientation has no significant effect on organizational innovation. The results of this study support the results of research Han, Kim and Srivasta (1996). The market orientation deals with organizational structures and administrative processes that are indirectly related to the basic activities of the work of an organization and directly relates to organizational management. The market orientation conducted by BUMD East Java is also related to the specification of tasks, jobs and information, and the equipment used, for the production of a product or making services.

\section{The Influence of Transformational Leadership to Market Performance}

The result of SEM analysis shows that transformational leadership has no significant effect on market performance. The findings of this study are incompatible with the transformational leadership theory which states that leadership in organizations today is moving toward transformational leadership that can inspire employees to perform optimally and improve market performance. The insignificant results of this study indicate also the inability of leaders to perform the necessary transformational roles to improve market performance. The findings 
of this study extend the results of previous research conducted by Gowen (2009), who found that transformational leadership does not directly affect the market performance.

Transformational leadership assessed in this research is on BUMD with leadership tendency conducted by general manager who entered in executive leadership. The flexibility of executive leadership is limited by internal organizational factors such as power and coalitions within the organization.

\section{Conclusion}

\section{CONCLUSIONS AND RECOMMENDATIONS}

1. Transformational leadership has a significant effect on market orientation.

2. Transformational leadership has a significant effect on organizational innovation.

3. Market orientation has no significant effect on marketing performance.

4. Organizational innovation has a significant effect on marketing performance.

5. Transformational leadership has no significant effect on marketing performance.

6. Market orientation has a significant effect on organizational innovation.

\section{Suggestion}

1. For BUMD managers still implement transformational leadership principles such as providing good examples in work, fostering optimism in working through individual motivation, giving ideas of ideas in the work.

2. For marketing managers should strive to improve the degree of market orientation in an effort to improve organizational innovation and better market performance. This can be done by improving the coordination between the functions of the company, because these factors reflect the coordinated utilization of all resources in the company.

3. BUMD companies also need to improve their ability to innovate with the support of the market orientation of the members of the company. Innovation is a corporate mechanism to adapt in a dynamic environment with both process, product and administrative innovation.

\section{References}

Agarwal, S., Erramilli, K., Dev. Chekitan, S., 2003, Market Oriented and Performance in Service Firms: Role of Innovation, Journal of Services Marketing, Vol. 17, No. 1, pp.68-82.

Avolio, BJ., and Bass, BM., 2002, Developing Potential Across a Full Range of Leadership: Cases on Transactional and Transformational Leadership, Mahwah, NJ: Lawrence Erlbaum Associates, San Diego.

Baker, W.E., Sinkula, J.M., 2002, Market Orientation, Learning Orientation and Product Innovation: Delvirig into the Organization's Black Box, Journal of Market Focused Management, 5, 5-23.

Bass, B. M., \& Avolio, B. J., 1997, Full-range of leadership development: Manual for the Multifactor Leadership Questionnaire, Palo Alto, CA: Mind Garden.

Cooper, J. R, 1998, A Multidimensional Approach to the Adoption of Innovation. Management Decision, 36(8): 493-502.

Damanpour, F., 1991, Organizational innovation: A Meta-Analysis of effects of determinants and moderators, Academy of Management Journal, 34: 555-590.

Damanpour, Fariborz dan Marguirete Schneider, 2006, Phases of The Adoption of Innovation in Organizations: Effect of Enviroment, Organization and Top Managers, British Academy of Management. Vol. 17.

Dess, G. G., \& Picken, J. C., 2000, Changing roles: Leadership in the 21st century, Organizational Dynamics, 28 (3), 18-34.

Ellis, Paul, 2006, Market Orientation and Performance: A Meta Analysis and Cross-National Comparisons, Journal of Management Studies, Vol. 43, No. 5, pp. 1089. 
Gana, Frans, 2004, Leadership and Organizational Structure as a Determinant of Organizational Innovation, Majalah Usahawan, No. 05, Tahun XXXIII, Mei.

George S Day, Robin Wensley., 1992. Assesing Advantage : A Framework for Diagnosing Competitive Superiority, Journal of Marketing, April.

Gowen, Charles R, Henagan, Stephanie C, and McFadden, Kathleen L, 2009, Knowledge management as a mediator for the efficacy of transformational leadership and quality management initiatives in U.S. health care, Health Care Management Review, 34 (2), 129140.

Han et al. 1998. "Market Orientation, Innovativeness, Product Innovation and Performance in Small Firm". Journal of Small Business Management Vol 42 No.2.

Han et al. 1998. Market Orientation and Organizational Performance: Is Innovation a missing link? Journal of Marketing.4: 30-45.

Han, J.K, Kim, N., and Srivastava, R., 1998, Market Orientation and Organizational Performance: Is Innovation A Missing Link?, Journal of Marketing, Vol. 62, October, pp.30-45.

Harris, L.0 and Ogbonna; E., 2001, Leadership style and market orientation: an . empirical study, European Journal of Marketing, Vol. 35, No. 5/6, pp. 744-764.

Hatani, La, 2000, The Effect of Market Orientation on Marketing Performance in Muna Regency. Jurnal Manajemen Unhalu.

Jarowski, B.J. dan Kohli, A.K, 1993 : Market Orientation and Consequences, Journal of Marketing, 57(3) ,53-70.

Jaworski, B.J. and Kohli, A.K., 1993, Market Orientation, Antecedents and Consequences, Journal of Marketing, Vol 57, July, pp. 53-70.

Kara, Ali John E. Spillan and Oscar W. Deshields, Jr. ,2005, An Empirical Investigation of The Effect of A Market Orientation on Business Performance: A Study of Small-Sized Service Retailers UsingMARKOR Scale, Journal of Small Business Management, Vol. 43 No. 2, pp.105-118.

Lukas, B.A. and O.C. Ferrell, 2000, The Effect of Market Orientation on Product Innovation, Journal of Academy of Marketing Science, Vol. 28, No.pp. 239-247.

Mavondo, Felix, T. Chimhanzi, Jacqueline, Stewart, Jillian, 2005, Learning Orientation and Market Orientation: Relationship with Innovation, Human Resource Practices and Performance, European Journal of Marketing, Vol. 39, No. 11/12, pp. 1235-1263.

Morgan, R.E. Katsikeas, C.S and Adu, Kwaku, A., 1998, Market Orientation and Organizational Learning Capabilities, Journal of Marketing Management, Vol. 14, No. 4/5, pp. 353-381.

Nasution, Hanny N. 2005. Organizational innovation: Concepts and Measurements, Usahawan, No.09 TH XXXIV September: 2005.

Pillai, William, 2004, Transformational leadership, self-efficacy, group cohesiveness, commitment, and performance, Journal of Organizational Change Management, Volume 17, Issue 2

Rafferty, A. E., \& Griffin, M. A, 2004, Dimensions of Transformational Leadership: Conceptual and Empirical Extensions. The Leadership Quarterly, 15(3):329-354.

Senge, P.M, 1994, The Fifth Discipline Fieldbook, Doubleday \& Currency, NY.

Tjiptono, Fandy. 2008. Strategic Marketing. Yogyakarta : Andi Offset.

Yukl, Gary A., 2009, Leadership in Organizations, (in Bahasa Indonesia), PT. Indeks, Jakarta. 